\section{An Exploration across Institution Types of Undergraduate Life Sciences Student Decisions to Stay in or Leave an Academic-Year Research Experience}

\author{
Logan E. Gin, ${ }^{\dagger}$ Carolyn E. Clark, ${ }^{\ddagger}$ Deanna B. Elliott, ${ }^{\ddagger}$ Travis B. Roderick, ${ }^{\ddagger}$ \\ Rachel A. Scott, ${ }^{*}$ Denisse Arellano, ${ }^{\ddagger}$ Diana Ramirez, ${ }^{\ddagger}$ Cindy Vargas, ${ }^{*}$ \\ Kimberly Velarde, ${ }^{\ddagger}$ Allyson Aeschliman, ${ }^{\ddagger}$ Sarah T. Avalle, ${ }^{\ddagger}$ Jessica Berkheimer, ${ }^{\ddagger}$ \\ Rachel Campos, ${ }^{\prime}$ Michael Gerbasi,, Sophia Hughes, ${ }^{\ddagger}$ Julie A. Roberts," \\ Quinn M. White, ${ }^{\ddagger}$ Ehren Wittekind, ${ }^{\ddagger}$ Yi Zheng, ${ }^{5}$ Katelyn M. Cooper, ${ }^{+\|}$and \\ Sara E. Brownell ${ }^{\dagger \| *}$ \\ ${ }^{\dagger}$ Research for Inclusive STEM Education Center, School of Life Sciences; ”NSF LEAP Scholars, \\ Research for Inclusive STEM Education Center; ${ }^{\circledR}$ Mary Lou Fulton Teachers College, Arizona State \\ University, Tempe, AZ 85281
}

\begin{abstract}
Undergraduate research is one of the most valuable activities an undergraduate can engage in because of its benefits, and studies have shown that longer experiences are more beneficial. However, prior research has illuminated that undergraduates encounter challenges that may cause them to exit research prematurely. These studies have been almost exclusively conducted at research-intensive (R1) institutions, and it is unclear whether such challenges are generalizable to other institution types. To address this, we extended a study previously conducted at public R1 institutions. In the current study, we analyze data from 1262 students across 25 public R1s, 12 private R1s, 30 master's-granting institutions, and 20 primarily undergraduate institutions (PUIs) to assess 1 ) to what extent institution type predicts students' decisions to persist in undergraduate research and 2) what factors affect students' decisions to either stay in or consider leaving their undergraduate research experiences (UREs) at different institution types. We found students at public R1s are more likely to leave their UREs compared with students at master's-granting institutions and PUls. However, there are few differences in why students enrolled at different institution types consider leaving or choose to stay in their UREs. This work highlights the importance of studying undergraduate research across institutions.
\end{abstract}

\section{INTRODUCTION}

Administrators and faculty at all types of colleges and universities should work together within and, where feasible, across institutions to create a culture that supports the development of evidence-based, iterative, and continuous refinement of undergraduate research experiences, in an effort to improve student learning outcomes and overall academic success.

—National Academies of Sciences and Medicine (2017)

Undergraduate research experiences (UREs) in science have the potential to be transformative for students (National Academies of Sciences and Medicine, 2017, 2019). Shifting undergraduate science students from the role of learners to becoming active contributors of new scientific knowledge allows them to broaden their perspectives on the research enterprise and what it means to be a practicing scientist
Rachelle Spell, Monitoring Editor Submitted Apr 28, 2021; Revised Jun 25, 2021; Accepted Jun 30, 2021

CBE Life Sci Educ September 1, 2021 20:ar47

DOI:10.1187/cbe.21-04-0108

"These authors contributed equally to this work. *Address correspondence to: Sara E. Brownell (Sara.Brownell(aasu.edu).

(C) 2021 L. E. Gin et al. CBE-Life Sciences

Education $\odot 2021$ The American Society for Cell Biology. This article is distributed by The

American Society for Cell Biology under license from the author(s). It is available to the public under an Attribution-Noncommercial-Share Alike 3.0 Unported Creative Commons License (http://creativecommons.org/licenses/ by-nc-sa/3.0).

"ASCB®" and "The American Society for Cell Biology $\AA^{\prime \prime}$ are registered trademarks of The American Society for Cell Biology 
(Lave and Wenger, 1991). UREs have been shown to result in a myriad of benefits to students, including the development of critical-thinking skills (Bauer and Bennett, 2003), persistence in biology and obtaining a bachelor's degree (Jones et al., 2010), and expressing interest in and pursuing a science, technology, engineering, and mathematics (STEM) graduate degree (Bauer and Bennett, 2003; Seymour et al., 2004; Russell et al., 2007; Carter et al., 2009; Eagan et al., 2013). Students benefit from longer research experiences by leveraging those experiences into greater benefits (Zydney et al., 2002; Russell et al., 2007; Thiry and Laursen, 2011; Prunuske et al., 2013; Adedokun et al., 2014; Daniels et al., 2016; Haeger and Fresquez, 2016). The recognition of undergraduate research as a high-impact practice that can enhance graduation rates and career success (Sandeen, 2012) has prompted national recommendations to involve every undergraduate science student in research (President's Council of Advisors on Science and Technology, 2012).

Although the literature on the impact of UREs is primarily positive, recent research has illuminated the need to examine the quality of UREs, because not all UREs are positive experiences (Mabrouk and Peters, 2000; Bernier et al., 2005; Dolan and Johnson, 2009, 2010; Howitt et al., 2010; Thiry and Laursen, 2011; Rowland et al., 2012; Cooper et al., 2019a; Limeri et al., 2019). For example, there has been some research examining students' experiences being mentored in UREs that has highlighted the importance of improving the quality of research mentoring provided to students (Mabrouk and Peters, 2000; Bernier et al., 2005; Dolan and Johnson, 2009, 2010; Thiry and Laursen, 2011; National Academies of Sciences and Medicine, 2019). Specifically, Limeri and colleagues investigated mentoring in research labs and characterized what constitutes negative mentoring (Limeri et al., 2019). This study identified seven ways in which undergraduate researchers experienced negative mentoring, which included: absenteeism, abuse of power, interpersonal mismatch, lack of career support, lack of psychosocial support, misaligned expectations, and unequal treatment. Moreover, one study conducted at an elite, research-intensive institution showed that students who were poorly supported by their research supervisors left their experiences feeling as though they were inadequate and found science to be too difficult and boring (Howitt et al., 2010). Other studies have shown that students can have less than ideal experiences in undergraduate research if they have difficulties prioritizing the time commitments and balancing the competing demands of a URE with other responsibilities as a student (Mabrouk and Peters, 2000; Rowland et al., 2012). Further, in a prior study by our own research group focused on why students might consider leaving UREs at research-intensive institutions, we identified aspects of UREs that contribute to a student's decision to consider leaving (Cooper et al., 2019a). Most notably, we identified the lab environment, which includes the culture of the lab and the interpersonal relationships that a student may have with other members of the lab, as a novel factor that can both encourage a student to persist in and prompt a student to leave a URE (Cooper et al., 2019a). These studies indicate that we cannot assume that all research experiences are positive and that we need to further examine how to improve UREs to maximize the benefits for students.

Further, we must acknowledge the need to do research on UREs across institution types so that we do not inadvertently generalize beyond the specific context of the research literature (National Academies of Sciences and Medicine, 2017). UREs can be influenced by the number and variety of research opportunities available, the structure and size of research labs, and whether the primary mentor is a faculty member or a postgraduate trainee; institution types (e.g., research-intensive institution or primarily undergraduate teaching institution) often differ in these factors, and thus, institution type may potentially influence the experiences of students in research. While the emergent body of work on UREs has established potential targets for interventions aiming to improve UREs, it is important to note that the majority of this work has either been conducted at research-intensive institutions (e.g., Cooper et al., 2019a) or has been conducted across different institution types but has not disaggregated findings based on where students were engaging in UREs (e.g., Aikens et al., 2017; Joshi et al., 2019; Limeri et al., 2019). We predict that the specific context of the institution would be significant and that different patterns and conclusions would emerge based on institution type, which could affect which interventions would be most effective at a particular type of institution.

Specifically, there are notable differences between institution types that could significantly limit the generalizability of some of these findings about UREs. Primarily undergraduate institutions (PUIs) do not typically have graduate students or postdocs in research labs as mentors, so the sole mentors for these students are faculty members. However, undergraduate researchers at research-intensive institutions are likely to have both a faculty mentor and a postdoc or graduate student mentor, which gives them multiple levels of mentorship in what have been called mentoring triads (Dolan and Johnson, 2009, 2010; Aikens et al., 2016; Bradley et al., 2017; Joshi et al., 2019). While interactions specifically with faculty members have been shown to be positive for undergraduate students in these mentoring triads (Joshi et al., 2019), students at research-intensive institutions have described unique benefits of interacting closely with a graduate student or postdoctoral scholar as a mentor (Aikens et al., 2016). For example, recent research on students with depression has indicated that students may feel more comfortable sharing their mental health struggles with graduate mentors rather than faculty members (Cooper et al., 2020c) and that graduate mentors can provide helpful support to undergraduates with depression in their lab (Cooper et al., 2020b). Additionally, prior literature has documented that there are significant gaps in publishing rates at comprehensive master's-granting institutions and liberal arts colleges when compared with research-intensive universities (Henderson, 2011). It is well established that the total research activity is different between research-focused institutions and teaching-focused institutions because of the differential teaching and research workload expected of faculty members. One study found that, in general, faculty at master's-granting institutions are less likely to be engaged in research activities, and are consequently less likely to provide UREs, compared with research-intensive doctoral universities (Webber et al., 2013), although other studies have shown that students still have opportunities to engage in research at similar rates at these different institutions ( $\mathrm{Hu}$ et al., 2007). However, the nature of the student experience in undergraduate research may be different given the unique context of a particular institution. Resource-rich institutions such as 
private research-intensive institutions may provide students with research experiences that are more technologically advanced, given their likely greater access to expensive reagents, core research facilities, automated technologies, or even technical support staff compared with resource-limited institutions such as public master's-granting institutions. The lower expectations for research productivity for faculty may influence the undergraduate student experiences in research at a small liberal arts college or a comprehensive master's-granting institution so that they are less focused on student research productivity and intention to publish (Henderson, 2011). However, student coauthorship can be a motivator for students' engagement in research (Cooper et al., 2021), and coauthorship on peer-reviewed publications is a tangible outcome of research that students can leverage as they apply for advanced degree programs or laboratory positions (Cooper et al., 2019b).

There are also significant variations in the makeup of the student body at different types of institutions. For example, $74 \%$ of students at the top 146 highly selective colleges came from families in the top quartile of socioeconomic status, measured by combining family income and the education and occupations of the parents; however, just 3\% came from the bottom socioeconomic status quartile (Carnevale and Rose, 2013). These highly selective institutions tend to be private research-intensive institutions or small liberal arts colleges (U.S. News \& World Report, 2021). In contrast, students from lower socioeconomic backgrounds are more likely to enroll in less-selective public and comprehensive institutions (Titus, 2006). Thus, student demographic differences among institution types, not necessarily differences in the research experience, could impact conclusions drawn about UREs.

If we as a research community do not make an effort to examine whether findings from research-intensive institutions can be replicated across other institution types, it is impossible to know how generalizable the findings are. As such, key stakeholders running research programs at other institution types, such as master's-granting institutions or PUIs, may lack the research literature needed to inform decision making if the studies are focused exclusively on R1, research-intensive institutions. We know of no study that has systematically examined student experiences in UREs across institution types, particularly related to factors that impact student persistence in their experiences. To begin to systematically explore these gaps in the literature, we set out to conduct a national study of undergraduate researchers at public R1 institutions, private R1 institutions, master's-granting institutions, and PUIs. Our specific research questions were as follows:

1. To what extent does institution type predict students' decisions to persist in UREs?

2. What factors affect students' decisions to either stay in or leave their UREs at different institution types?

3. Do these factors differ across institution types?

\section{METHODS}

This study was approved by ASU's Institutional Review Board (IRB) study no. 7247.

This research project was conducted as part of a two-semester course-based undergraduate research experience (CURE) in science education in Fall 2019 and Spring 2020 taught by L.E.G. and S.E.B. Students in the CURE were community college transfer students who were engaged in scientific undergraduate research and were working in faculty research labs while they were taking the CURE, so they were familiar with undergraduate research in faculty member labs. In a CURE, students engage in a novel and broadly relevant research project in the context of a course (Auchincloss et al., 2014; Brownell and Kloser, 2015). One benefit of science education research CUREs is that students often are able to engage in the full research project, ranging from research question development to manuscript preparation (Cooper and Brownell, 2018; Cooper et al., 2018, 2019a; Nadile et al., 2021). A total of 18 students participated in the CURE and were involved in the research project. Collectively, the instructors and students were responsible for developing the research questions, collecting data, analyzing the data, interpreting the data, and communicating the findings. All data were collected before Spring 2020.

\section{Participant Recruitment}

The purpose of this study was to build on previous work that examined to what extent and why undergraduates at public institutions with very high research activity (public R1s) left their UREs prematurely (Cooper et al., 2019a). Given the literature that suggests that longer research experiences are more beneficial for students and that very few students are asked to leave research experiences by their mentors (Cooper et al., 2019a), we were interested in exploring what influenced the decision to stay in their research experiences until graduation or leave their research experiences before graduation. Specifically, we wanted to explore this overarching research question in the context of private institutions with very high research activity (private R1s), master's-granting colleges and universities, and baccalaureate colleges or PUIs so that we could compare our findings with what we had previously documented about public R1 institutions (Cooper et al., 2019a) to see whether institution type mattered.

Using Carnegie classifications, we identified all private R1 institutions, master's-granting institutions, and PUIs. We used college and university websites to identify individuals within life science departments (e.g., undergraduate biology program manager, life sciences program assistant) that likely would have access to a student email list or Listserv to send our recruitment script and survey out to their students. To constrain variation in our sample, we intentionally limited our sample to only life sciences students, because research experiences can vary across disciplines. This approach allowed for all students who were currently participating in undergraduate research in the life sciences to participate in our study. Of the 37 private R1 institutions we contacted, $12(32 \%)$ agreed to send the survey; of the 350 master's-granting institutions, $30(9 \%)$ agreed to send out the survey; and of the 241 baccalaureate colleges, $20(8 \%)$ agreed to send the survey out to their students. Because we relied on individuals within life sciences departments to distribute our survey, we do not know exactly how many students were contacted about the opportunity. To incentivize participation, students were offered a chance to win one of four $\$ 50$ gift cards for participating in the survey. 


\section{Survey Development}

The survey instrument used in this study was identical to the survey used to collect data at public R1 institutions, which is published in Cooper et al. (2019a). The survey instrument is included in the Supplemental Material. Previous validation of this survey included think-aloud interviews with undergraduate researchers, pilot testing, and iterative revision of the items. The full description of this process is described in detail in Cooper et al. (2019a).

Screening Questions. To limit participation to students who were currently participating or had previously participated in a URE, the survey first asked students whether they had participated in a URE either currently or in the past. In the survey, we defined a URE as working with an individual faculty member or in a faculty member's lab while enrolled in college. All students who had indicated they had not participated in research did not complete the rest of the survey. Students were then asked if they had only participated in a summer research experience that did not take place during the academic year, such as an NSF Research Experience for Undergraduates (REU). Because the main interest of this study was to explore why students leave their UREs prematurely, our goal was to only include UREs that students likely had the opportunity to participate in until they graduated, which would exclude students who selected that they only participated in research during the summer and not during the academic year. Our past research has indicated that few students are asked to leave research experiences, so most have the option of continuing to do research until graduation, and we did collect data on these students about whether they were asked to leave (Cooper et al., 2019a). We also did not include students in research experiences with a finite end point such as CUREs or introductory research programs that only are a single semester, as there would be no decision about leaving when the term ended (Auchincloss et al., 2014; Brownell and Kloser, 2015). Our pilot studies and student open-ended responses indicate that students interpreted these questions to only mean undergraduate research in a faculty lab that did not have a finite end point prior to graduation. After these screening questions, students were asked whether they had ever considered leaving or actually left their first UREs. Students' responses to this question allowed us to classify students who never considered leaving their first research experiences as stayers. Students who considered leaving their research experiences but ultimately stayed are referred to as waverers. Finally, students who left their research experiences are referred to as leavers.

Questions to Identify Why Students Chose to Stay in Their UREs. All students who ultimately chose to stay in their first UREs (stayers and waverers) were first asked an open-ended question about why they chose to stay in their first research experiences. Students were then given a list of 11 factors that may have caused them to stay in their UREs: 1) Research experience is important for my future career, 2) Doing research positively contributes to my financial situation, 3) I have enough time to do research, 4) I am concerned I may not have another research opportunity, 5) My mentor who is a PI/faculty member/grad student/postdoc/staff member, 6) The overall environment of my lab, 7) The lab is flexible with my schedule/ time, 8) I have sufficient guidance for my research project, 9) I enjoy my everyday research tasks, 10) I am interested in my research topic, and 11) I am gaining important skills and knowledge. These factors were identical to the ones used in our previous study of R1 public institutions and were originally developed based on a pilot survey of 126 undergraduate researchers (Cooper et al., 2019a). Students were asked to select all factors that caused them to stay in their UREs or to select that none of the factors applied to them. The purpose of using both openand closed-ended questions was to collect data on all of the possible reasons for why students might choose to stay in their research experiences (closed-ended question) in addition to their most salient reasons for staying in research (open-ended question). The closed-ended item was presented to students after the open-ended item so that it would not bias students' responses to the open-ended question.

Questions to Identify Why Students Considered Leaving Their UREs. Similarly, students who considered leaving their first UREs but ultimately stayed (waverers) and students who considered leaving their first UREs and left (leavers) were given an open-ended question asking them why they considered leaving their UREs: 1) Research experience is not/was not important for my future career, 2) I need/needed to spend my time making more money than I make/was making doing research, 3) I do not/did not have enough time to do research, 4) I am interested/was interested in another research opportunity, 5) My mentor who is a PI/faculty member/grad student/postdoc/ staff member, 6) The overall environment of my lab, 7) The lab is not/was not flexible with my schedule/time, 8) I do not/did not have sufficient guidance for my research project, 9) I do not/did not enjoy my everyday research tasks, 10) I am not/ was not interested in my research topic, and 11) I am not/was not gaining important skills and knowledge. These factors were also identical to the ones used in our previous study of R1 public institutions and were originally developed based on a pilot survey of 126 undergraduate researchers (Cooper et al., 2019a). Students were asked to select all factors that caused them to consider leaving their first UREs or to select that none of the factors applied to them.

\section{Analysis}

Data Set. We were interested in whether the type of institution that students attended predicted whether they would ultimately choose to leave their UREs. As such, we combined the data from our survey of undergraduate researchers at public R1s (Cooper et al., 2019a) with our new data set of undergraduate researchers from private R1s, master's-granting institutions, and PUIs. A total of 1262 undergraduate students who had conducted undergraduate research were classified as stayers, waverers, or leavers and were included in the analyses.

To What Extent Does Institution Type Predict Student Decisions to Persist in UREs? We used logistic regression to determine to what extent institution type predicted whether students had never considered leaving (stayer), considered leaving but ultimately stayed (waverer), or actually left (leaver) their first UREs. Institution type was identified by the Carnegie classification of the institution where students engaged in their first UREs and included public R1, private R1, 
master's-granting, and PUI. Additionally, our previous work demonstrated that student demographics can predict to what extent students stay in or leave research (Cooper et al., 2019a). Therefore, we chose to control for student demographics in our logistic regression models. We did not have a large enough sample size to be able to test whether the impact of demographics varies by institution type. The student demographic variables that were included in the analysis were gender (man, woman), race/ethnicity (white, Asian, and a category that included Black/Latinx/Native American/Pacific Islander students), college generation status (non-first generation, first generation), and grade point average (GPA). We recognize that not all students identify as gender binary (e.g., man or woman). However, there were too few students who identified as a gender other than man or woman to create a third category, so these individuals' gender data were not included in the analysis (Cooper et al., 2020a). We included students who identify as Black or African American, Latinx, American Indian or Alaska Native, and Pacific Islander in one category that we abbreviate as BLNP. These students share the experience of being underserved by institutions of higher education; while racial experiences within this group likely vary, the small sample sizes of Black, American Indian or Alaska Native, and Pacific Islander students necessitated that we pool these identities with Latinx students as the single factor that we call BLNP in our analyses. Our model allowed us to test the extent to which student decisions to either stay in, consider leaving, or actually leave their first UREs was predicted by institution type and student demographics (model: decision (stay/wave/ leave) institution type + gender + race/ethnicity + generation status + GPA). We used students who never considered leaving (stayers) as the reference group in this model.

We specifically chose not to nest students within a single institution in any of our analyses, because we had no reason to think that the experience of any two students in different labs at a single institution would be the same and thus would be fundamentally different from the experience of students at another institution. We also did not collect identifying information about the research lab that a student was a member of to help anonymize the identity of the students and mentors and to encourage them to share honestly about their experiences.

What Factors Affect Students' Decisions to Stay in and Consider Leaving Their UREs? In our 2019 study, we analyzed students' responses to the same questions that were included on this survey about why students stayed in their UREs and why they considered leaving their UREs (Cooper et al., 2019a). We used the rubrics developed in that study to code students' responses to the two open-ended questions asking: 1) why they stayed in their UREs and 2) why they considered leaving their UREs. A team of five researchers (L.E.G., C.E.C., D.B.E., T.B.R., R.A.S.) were trained to use the original rubrics. For each question, this team coded a subset of the data with the respective rubric and carefully examined whether there were new themes from the new data set (including data from private R1s, master's-granting institutions, and PUIs) that had not been accounted for in the first set of public R1 data. For both questions, no additional themes were identified. The group of five coders then used the respective rubrics to independently code all responses from undergraduate researchers at private R1s, master's-granting institutions, and PUIs for 1) why students stayed in their UREs and 2) why students considered leaving or left their UREs. For each question, the coding team came together to review their codes and discuss any coding discrepancies until coming to consensus (Bradley et al., 2007). Within a student's response, a single phrase could only be coded as one theme; however, students' responses often included multiple phrases, each of which was coded as a different theme.

The responses to the closed-ended factors students selected that impacted their decisions to stay in their UREs or to consider leaving their UREs were tallied. For each question, why students stayed in their UREs and why students considered leaving their UREs, we compared the coding of our open-ended data with the most frequently selected closed-ended factors. The coding of the open-ended responses generally reflected the closed-ended data for each question. For brevity, we report only the closed-ended data. The descriptions of the themes, example student quotes, and the proportion of students who mentioned each theme in the open-ended questions about why students stay in their UREs and consider leaving their UREs are included in the Supplemental Material.

To What Extent Does Institution Type Predict Specific Reasons for Considering Leaving Research? We used logistic regression to determine to what extent institution type predicts specific reasons students considered leaving their first UREs. We used the closed-ended question asking students to select any of the 11 factors that influenced their decisions to consider leaving their UREs. Because student demographics have been shown to predict the factors that influence students' decisions in undergraduate research (Cooper et al., 2019a), we controlled for demographics in our model (model: whether student checked a particular factor for leaving $[\mathrm{Y} / \mathrm{N}] \sim$ institution type + gender + race/ethnicity + college generation status + GPA).

To What Extent Does Institution Type Predict Specific Reasons for Staying in Research? We also used logistic regression to determine to what extent institution type predicts specific reasons for why students choose to stay in their first UREs. We used the closed-ended question asking students to select any of the 11 factors that influenced their decisions to stay in their UREs (model: whether student checked a particular factor for staying $[\mathrm{Y} / \mathrm{N}] \sim$ institution type + gender + race/ethnicity + college generation status + GPA).

There are several ways to interpret model coefficients from logistic regression; the most accessible way is to interpret the natural exponential of the estimated coefficient, which is the factor of change in odds that students at a particular type of institution (e.g., R1 vs. master's) will stay in their UREs (e.g., stayed in their research experiences vs. left their research experiences), also referred to as the "odds ratio." The odds ratio can be considered a standardized effect size statistic, because the explanatory variable, whether a student stayed or left a URE, is binary (Deeks, 1998; Agresti and Franklin, 2012). Odds ratios, or "likelihood" that a student is in a particular category or that a factor is selected, are reported for the logistic regressions in this study. Thus, we will summarize our results with the language "X.X times more likely." (e.g., "Women were 3.0 times more likely than men to report leaving because the lab was not flexible with their schedule.") 
We also recognize that the significance of a result from any statistical test is continuous rather than dichotomous based on the specific $p$ value (Wellek, 2017). However, we report select results by the criterion of $p \leq 0.05$ throughout the Results section for simplicity. We acknowledge that test results with $p$ values greater than 0.05 can still be scientifically meaningful; thus, we report out all results of statistical tests in the Supplemental Material for further interpretation.

\section{RESULTS}

\section{Description of Undergraduate Researchers and UREs by Institution Type}

A total of 1262 students completed the survey and were included in the analysis: 760 students from 25 public R1 institutions, 248 from 12 private R1 institutions, 150 from 30 master's-granting institutions, and 104 from 20 PUIs (see Supplemental Table S1 for a list of all anonymized institutions, including institution type and geographic region). A comparison of student-level demographics across institution types can be found in Table 1 . We cannot directly compare students' likelihood of engaging in research across different institution types based on their demographics, as we do not know the demographic breakdown of each institution type.

The experiences of undergraduate students in research differed among institution types. Characteristics of students' research experiences, including their primary mentors, average number of hours in research, and compensation can be found in Table 2. A notably higher percentage of students listed a primary investigator (PI) as the primary research mentor at master's-granting institutions and PUIs compared with public and private R1s, which is expected given the mentoring hierarchy that exists at R1 institutions. Additionally, at public R1s, a higher percentage of students reported volunteering for their research positions compared with master's-granting institutions and PUIs.

\section{Finding 1. Students at Public R1s Are More Likely to Leave Their UREs Compared with Students at Master's-Granting Institutions and PUIs}

From our sample, $50.5 \%$ of students at public R1s and $47.6 \%$ of students at private R1s never considered leaving their UREs. However, a greater proportion of students at master's-granting institutions and PUIs never considered leaving their UREs (78.0\% and 68.3\%, respectively). Compared with students at public R1s, students at master's-granting institutions were 2.8 times less likely to consider leaving their UREs $(p<0.001)$ and 4.5 times less likely to actually leave their UREs $(p<0.001)$. Similarly, compared with students at public R1 institutions, students at PUIs were 2.5 times less likely to consider leaving their UREs ( $p=0.005)$ and 2.8 times less likely to actually leave their UREs $(p=0.001)$. There was no difference between students at private R1s and public R1s. See Table 3 for the percent of those who never considered leaving (stayers), those who considered leaving but stayed (waverers), and those who considered leaving and left (leavers) from each institution type and the Supplemental Material for the output of the logistic regression.

Similar to what had been found previously when we examined student demographics at public R1 institutions (Cooper et al., 2019a), when examining aggregated demographics

TABLE 1. Summary of student demographics organized by institution type

\begin{tabular}{|c|c|c|c|c|}
\hline & $\begin{array}{l}\text { Public R1 } \\
(n=760)\end{array}$ & $\begin{array}{c}\text { Private R1 } \\
(n=248)\end{array}$ & $\begin{array}{l}\text { Master's } \\
(n=150)\end{array}$ & $\begin{array}{c}\text { PUI } \\
(n=104)\end{array}$ \\
\hline \multicolumn{5}{|l|}{ Student-level demographics } \\
\hline \multicolumn{5}{|l|}{$\underline{\text { Gender }}$} \\
\hline Woman & $74.1 \%(563)$ & $77.0 \%(191)$ & $75.3 \%(113)$ & $77.9 \%(81)$ \\
\hline Man & $24.1 \%(183)$ & $22.2 \%(55)$ & $22.7 \%(34)$ & $19.2 \%(20)$ \\
\hline Other & $0.7 \%(5)$ & $0.4 \%(1)$ & $0.7 \%(1)$ & $1.9 \%(2)$ \\
\hline Decline to state & $1.2 \%(9)$ & $0.4 \%(1)$ & $1.3 \%(2)$ & $1.0 \%(1)$ \\
\hline \multicolumn{5}{|l|}{$\underline{\text { Race/ethnicity }}$} \\
\hline Asian & $26.4 \%(201)$ & $23.0 \%(57)$ & $10.0 \%(15)$ & $10.6 \%(11)$ \\
\hline Black/Latinx/Native American/Pacific Islander (BLNP) ${ }^{\mathrm{a}}$ & $13.7 \%(104)$ & $12.1 \%(30)$ & $6.7 \%(10)$ & $9.6 \%(10)$ \\
\hline White & $54.1 \%(411)$ & $58.5 \%(145)$ & $76.7 \%(115)$ & $74.0 \%(77)$ \\
\hline Other $^{b}$ & $3.4 \%(26)$ & $5.2 \%(13)$ & $2.7 \%(4)$ & $4.8 \%(5)$ \\
\hline Decline to state & $2.4 \%(18)$ & $1.2 \%(3)$ & $4.0 \%(6)$ & $1.0 \%(1)$ \\
\hline \multicolumn{5}{|l|}{ College generation status } \\
\hline First generation & $29.1 \%(221)$ & $16.1 \%(40)$ & $36.7 \%(55)$ & $19.2 \%(20)$ \\
\hline Non-first generation & $69.3 \%(527)$ & $82.7 \%(205)$ & $60.7 \%(91)$ & $78.8 \%(82)$ \\
\hline Decline to state & $1.6 \%(12)$ & $1.2 \%(3)$ & $2.7 \%(4)$ & $1.9 \%(2)$ \\
\hline \multicolumn{5}{|l|}{$\underline{\mathrm{GPA}}$} \\
\hline Mean & 3.56 & 3.65 & 3.56 & 3.58 \\
\hline SD & 0.40 & 0.30 & 0.35 & 0.33 \\
\hline
\end{tabular}

alack/Latinx/Native American/Pacific Islander (BLNP) includes students who identified as Black or African American, Hispanic, Latinx, or of Spanish origin, American Indian or Alaska Native, and Pacific Islander.

'Other includes students who identified as "other" and wrote in a race/ethnicity not listed on the survey, such as Middle Eastern or multiracial. 
TABLE 2. Research experience-level demographics and characteristics of student research experiences

\begin{tabular}{|c|c|c|c|c|}
\hline & $\begin{array}{l}\text { Public R1 } \\
(n=760)\end{array}$ & $\begin{array}{c}\text { Private R1 } \\
(n=248)\end{array}$ & $\begin{array}{l}\text { Master's } \\
(n=150)\end{array}$ & $\begin{array}{c}\text { PUI } \\
(n=104)\end{array}$ \\
\hline \multicolumn{5}{|l|}{ Research-level demographics } \\
\hline \multicolumn{5}{|l|}{ Primary mentor } \\
\hline Principal investigator (PI) & $28.3 \%(215)$ & $24.2 \%(60)$ & $76.0 \%(114)$ & $74.0 \%(77)$ \\
\hline Postdoc & $13.4 \%(102)$ & $17.7 \%(44)$ & $1.3 \%(2)$ & $3.8 \%(4)$ \\
\hline Graduate student & $37.2 \%(283)$ & $36.7 \%(91)$ & $8.0 \%(12)$ & $1.9 \%(2)$ \\
\hline \multicolumn{5}{|c|}{ Average number of hours in research per week } \\
\hline $1-5$ & $18.4 \%(140)$ & $22.2 \%(55)$ & $38.0 \%(57)$ & $19.2 \%(20)$ \\
\hline $6-10$ & $51.2 \%(389)$ & $44.8 \%(111)$ & $40.0 \%(60)$ & $51.0 \%(53)$ \\
\hline $11-15$ & $22.0 \%(167)$ & $18.5 \%(46)$ & $7.3 \%(11)$ & $14.4 \%(15)$ \\
\hline $16+$ & $8.4 \%(64)$ & $14.5 \%(36)$ & $13.3 \%(20)$ & $15.4 \%(16)$ \\
\hline Volunteer & $21.1 \%(160)$ & $16.9 \%(42)$ & $13.3 \%(20)$ & $10.6 \%(11)$ \\
\hline Decline to state & $0.0 \%(0)$ & $0.0 \%(0)$ & $0.7 \%(1)$ & $0.0 \%(0)$ \\
\hline
\end{tabular}

apercentages do not add up to $100 \%$, because students could choose multiple compensation types.

across all the institutions, women were 1.5 times more likely to consider leaving their UREs compared with men $(p=0.05)$. Further, for every 1-point increase in a student's GPA, students were 1.7 times more likely to actually leave their UREs ( $p=$ 0.02). There were no differences based on race/ethnicity or college generation status (see Supplemental Table S1).

TABLE 3. Percent of students who never considered leaving (stayer), considered leaving but stayed (waverer), and left (leaver) their UREs by institution type

\begin{tabular}{|c|c|c|c|}
\hline & $\begin{array}{c}\text { Stayers } \\
(n=690)\end{array}$ & $\begin{array}{l}\text { Waverers } \\
(n=265)\end{array}$ & $\begin{array}{c}\text { Leavers } \\
(n=307)\end{array}$ \\
\hline \multicolumn{4}{|l|}{ Institution type } \\
\hline Public R1 $(n=760)$ & $50.5 \%$ & $22.6 \%$ & $26.8 \%$ \\
\hline Private R1 $(n=248)$ & $47.6 \%$ & $24.2 \%$ & $28.2 \%$ \\
\hline Master's $(n=150)$ & $78.0 \%$ & $12.0 \%$ & $10.0 \%$ \\
\hline PUI $(n=104)$ & $68.3 \%$ & $14.2 \%$ & $17.3 \%$ \\
\hline Woman $(n=948)$ & $73.0 \%$ & $80.0 \%$ & $75.6 \%$ \\
\hline $\operatorname{Man}(n=292)$ & $25.5 \%$ & $18.7 \%$ & $21.5 \%$ \\
\hline Other $(n=9)$ & $0.4 \%$ & $1.1 \%$ & $1.0 \%$ \\
\hline Decline to state $(n=13)$ & $1.2 \%$ & $0.0 \%$ & $2.0 \%$ \\
\hline \multicolumn{4}{|l|}{$\underline{\text { Race/ethnicity }}$} \\
\hline Other $(n=48)$ & $4.3 \%$ & $3.0 \%$ & $3.3 \%$ \\
\hline Decline to state $(n=28)$ & $2.2 \%$ & $1.9 \%$ & $2.5 \%$ \\
\hline \multicolumn{4}{|l|}{ College generation status } \\
\hline First generation $(n=336)$ & $28.8 \%$ & $23.0 \%$ & $24.8 \%$ \\
\hline Non-first generation $(n=905)$ & $69.3 \%$ & $76.6 \%$ & $73.0 \%$ \\
\hline Decline to state $(n=21)$ & $1.9 \%$ & $0.4 \%$ & $2.2 \%$ \\
\hline \multicolumn{4}{|l|}{ GPA } \\
\hline Mean & 3.55 & 3.60 & 3.62 \\
\hline SD & 0.37 & 0.39 & 0.36 \\
\hline
\end{tabular}




\section{Finding 2. There Are Few Differences in Why Students Enrolled at Different Institution Types Considered Leaving Their UREs}

A summary of the factors that influenced students to consider leaving their first UREs are reported in Table 4. Students selected all factors that caused them to consider leaving their UREs from 11 predetermined reasons; students from each type of institution (public R1, private R1, master's-granting, and PUI) selected an average of three factors. The most reported reason for why students considered leaving collectively across institution types was that they did not enjoy their everyday research tasks (42.5\%). The second most common reason for students considering leaving was that they were interested in another research opportunity (39.7\%). Students also considered leaving their research experiences because they did not have enough time to do research (38.8\%). Furthermore, students considered leaving research because they did not have sufficient guidance for their research project (30.4\%) or because of their mentors, defined as a principal investigator, faculty mentor, graduate student, postdoc, or staff member that a student worked most closely with (29.0\%).

We examined whether institution type influenced what factors affected students' decisions and controlled for student demographics. The results of the 11 regression models can be found in the Supplemental Material. In the analysis, each institution type (private R1, master's-granting, PUI) was compared with public R1 institutions. We chose public R1 institutions as our comparison group because the majority of extant research about UREs has been conducted at public R1 institutions.

Notably, there were no observed significant differences between the percent of students at master's-granting institutions or PUIs when compared with students at public R1 institutions who selected each factor that affected the decision to consider leaving their UREs. Students from public R1 institutions were 1.7 times more likely than students at private R1 institutions to report leaving because they needed to make more money than they made doing research $(p=0.05)$. Additionally, compared with students from public R1 institutions, students from private R1 institutions were 1.9 times more likely to report leaving because they were not gaining important skills or knowledge $(p=0.01)$. Finally, students from private R1 institutions were 2.0 times more likely than students from public R1 institutions to report considering leaving because their labs were not flexible with their schedules $(p=0.02)$.

With regard to the relationship between student demographics and their reasoning for leaving research, our findings echo those reported in Cooper et al. (2019a); the significant demographic differences are highlighted in Table 4.

\section{Finding 3. There Are Few Differences Between Public R1 Students' and Private R1, Master's-Granting, and PUI Stu- dents' Reasoning for Staying in Their UREs}

A summary of the factors that influenced students to stay in their first UREs are reported in Table 5. Students selected all factors that caused them to stay in their UREs from 11 predetermined reasons; students from master's-granting institutions and private R1 institutions selected an average of six factors and students from public R1s and private R1s selected an aver- age of seven factors. When aggregated across all institution types, the most reported reason for why students stayed in their UREs was that research experience was important for their future careers $(84.0 \%)$. The second most common factor for staying in research was students felt they were gaining important skills and knowledge (83.8\%). The third most common reason students reported staying in their research was that their labs were flexible with their time and schedules (79.1\%). Students also chose to stay in their research experiences because of their research mentors (77.8\%). The fifth most common reason that influenced students staying in their research experiences was that they were interested in their research topics $(74.8 \%)$.

Below we summarize any institutional differences that emerged with regard to which students selected each of the 11 factors that may have influenced the decision to consider leaving their UREs. Once again, we used public R1 institutions as the comparison group in the model. The results of the 11 regression models can be found in the Supplemental Material.

Students at public R1 institutions were 1.6 times more likely than students at private R1s and 1.8 times more likely than students at master's-granting institutions to select staying in their UREs because their labs were flexible with their time and schedules ( $p=0.04, p=0.02)$. Moreover, students from public R1 institutions were 1.8 times more likely than students from PUIs to stay because their labs were flexible with their time and schedules $(p=0.05)$. Students from public R1 institutions were 1.5 times more likely than students from master's-granting institutions to stay because of the overall environment of their labs ( $p=0.05), 1.6$ times more likely to report staying because of having enough time to do research $(p=0.04)$, and 1.9 times more likely to report staying because research positively contributed to their financial situations $(p=0.04)$.

The effect of demographics on the factors affecting students' decisions echoes the findings in Cooper et al. (2019a) and are summarized in Table 5.

\section{DISCUSSION}

To address the concern that the majority of research done on UREs is conducted at research-intensive institutions, we collected and analyzed data across four institution types: public research-intensive institutions, private research-intensive institutions, master's-granting institutions, and PUIs to examine students' decisions to stay in or leave their UREs. Our large-scale data collection allowed us to analyze data from 1262 students from 25 public research-intensive institutions, 12 private research-intensive institutions, 30 master's-granting institutions, and 20 PUIs.

Students may engage in research and realize that it is not what they want to do, which could be a positive outcome of the research experience, even if they leave it prematurely. Given the limited time available for extracurricular activities, particularly for students who may have to work a job during their undergraduate studies, these students may choose to leave research and instead spend their time exploring other disciplinary learning experiences such as being an undergraduate learning assistant, a leader in a campus organization, or a volunteer in a clinic. However, studies have shown that the longer a student engages in a single research experience, the more likely the student is to experience benefits (Zydney et al., 2002; Russell et al., 2007; Thiry and Laursen, 2011; Prunuske et al., 2013; 


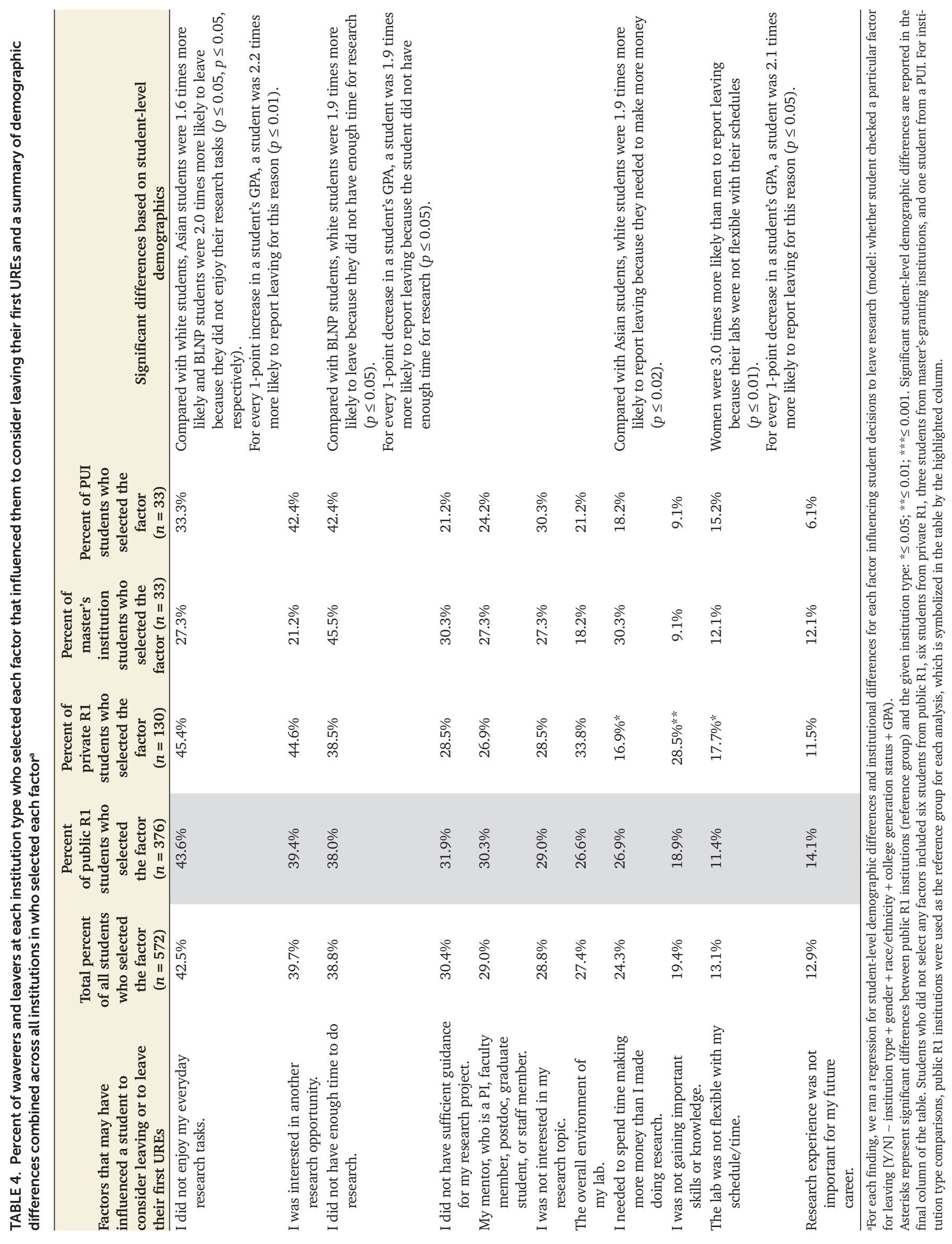




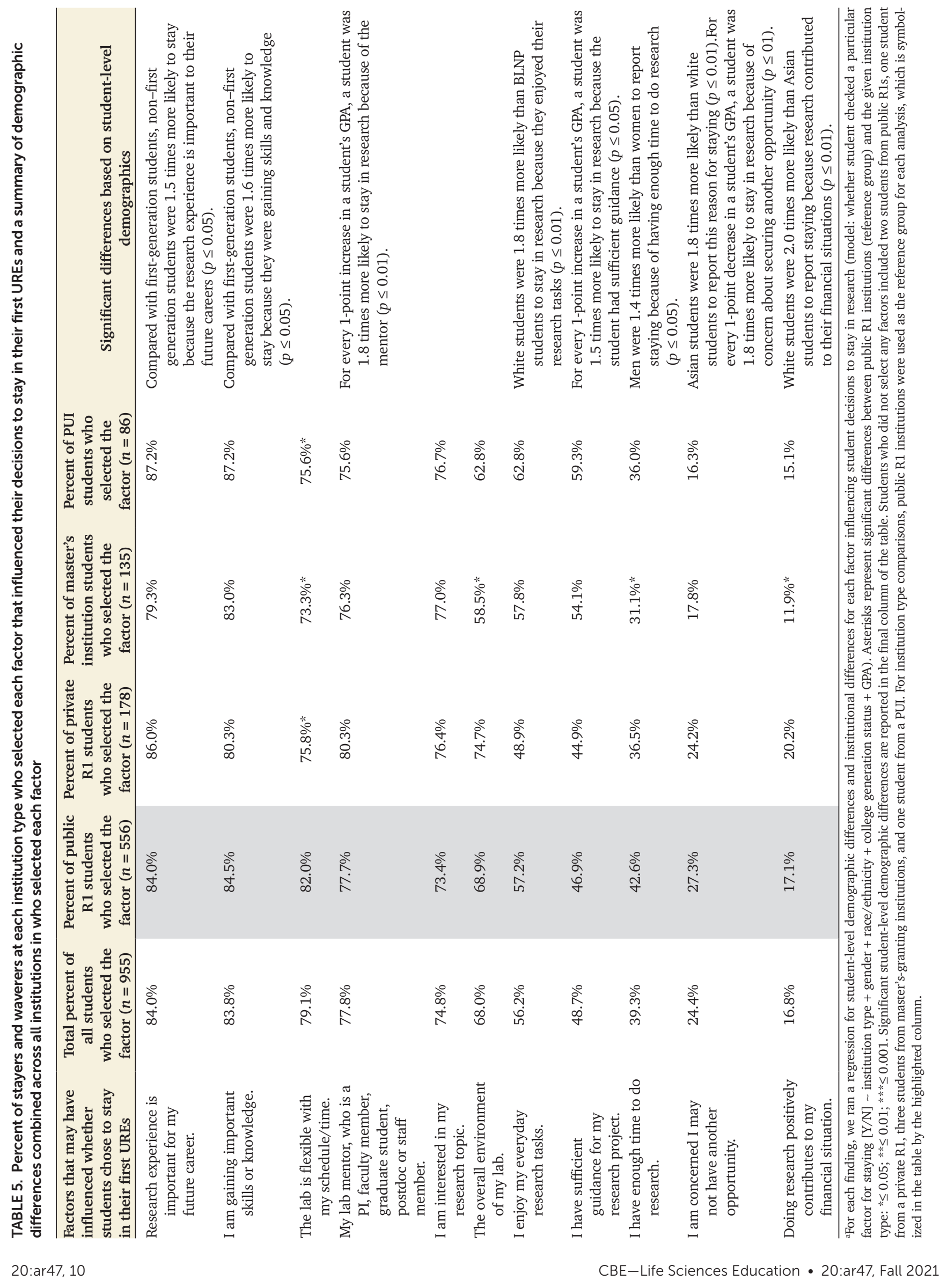


Adedokun et al., 2014; Daniels et al., 2016; Haeger and Fresquez, 2016). Specifically, results have shown that the longer students participate in research, the more likely they are to gain research skills such as analyzing data and problem solving (Thiry et al., 2012) and to develop confidence in their ability to do science, work independently, and collaborate with others (Daniels et al., 2016). Additionally, longer UREs have been shown to be a positive predictor of students' perceived ability to succeed in graduate school, actual research performance in STEM PhD programs, and pursuit of a career in STEM (Russell et al., 2007; Gilmore et al., 2015). As such, understanding what factors encourage students to engage in research for longer and what factors cause students to leave a research experience prematurely is integral for developing interventions to promote student retention in UREs and, consequently, in science. If students are leaving research because of negative experiences in research, especially if these experiences are differentially impacting certain groups of students, then we see this as a problem.

Our findings highlight that we cannot assume UREs to be equal across institution types. That is, students attending master's-granting institutions and PUIs were significantly less likely to leave their UREs compared with students enrolled at public R1s. Although there is often an assumption that research-intensive institutions are the best place to engage in research, our data highlight that this may not be the case when considering the longevity of student UREs. More research needs to be done to examine whether the benefits that students obtain also differs among institution types.

Despite the difference in student retention in UREs among institution types, we found relatively few significant differences in the percent of students who reported what factors caused them to stay in and/or consider leaving their UREs. However, the most common reasons why students considered leaving their UREs did differ among institution types. For example, students at public institutions were more likely to consider leaving their UREs because they did not enjoy their everyday research tasks versus students at master's-granting institutions and PUIs, who were most likely to report that they considered leaving because they did not have enough time to do research. While all undergraduate researchers likely participate in menial tasks that they may not enjoy as they integrate into the scientific community (Lave and Wenger, 1991), we hypothesize that the frequency at which students are engaging in these tasks and the extent to which they understand the impact of the tasks on the overall research project influences whether this becomes a factor that affects their willingness to persist in their experiences (Adedokun and Burgess, 2011). When considering only the students who considered leaving their research experiences, the percent of students who reported not enjoying their research tasks was not significant across institution types; however, we must consider that many more students considered leaving their research at public R1s. As such, when we consider all undergraduate researchers, not just those who considered leaving, a higher percentage of students report not enjoying their research experiences at public R1s (22\%) compared with master's-granting institutions (6\%) and PUIs (11\%). One hypothesis as to why this is would be is that students at master's-granting institutions and PUIs may have more intellectually engaging everyday research tasks, given that these institutions do not have $\mathrm{PhD}$ students. Thus, some of the more complex tasks that tend to be accomplished by $\mathrm{PhD}$ students at R1s may be given to undergraduates at master's-granting institutions and PUIs. An alternative way to look at this result is that perhaps $\mathrm{PhD}$ students and postdocs have their undergraduate researchers complete all the menial tasks that they themselves do not want to do. Students at master's-granting institutions and PUIs were more likely to be directly mentored by a PI compared with students at public R1s, which may also relate to the quality of tasks they are asked to accomplish. Additionally, students at master's-granting institutions and PUIs may be in smaller labs where they have the potential to see the impact of their tasks more directly, even if the tasks that they are performing may be menial.

Based on these findings, we have created a set of recommendations for research mentors to support undergraduate researchers (Table 6). Departments could use these recommendations to help train research mentors or research program directors could convey this information to students to help them find the best possible research experiences. These recommendations include the following:

1. Provide students with their perception of sufficient guidance. Make yourself available for students to ask questions or designate someone else they can address questions to. Check in with the student regularly. Reach out if you haven't heard from them.

2. Explain the why behind what you are doing in the lab. Help students see the big picture and how the small tasks that they are doing are important for answering the larger question. Be explicit about why particular tasks or knowledge are useful for them to know and how they could use them in future situations.

3. Be flexible with students. Offer students the option to work on their own time and to have sick days (including mental health days) and be cognizant that students are juggling research and course work. It might be helpful for students to work less in the lab during midterm or finals week.

4. Pay students. If funds are available, pay students so that they can do undergraduate research without having to work a side job.

5. Be nice and create a positive working environment. If you are frustrated, busy, or having a bad day, remember that your attitude has an impact on the undergraduate researchers. Take the time to say hello, ask them about their course work or career interests, and be supportive even when they make mistakes.

It is also important to note that not all students who considered leaving their UREs implied that they were permanently leaving research. Encouragingly, a high percentage of students across institution types, particularly public and private R1s and PUIs, reported that they considered leaving research because they were interested in another research opportunity. While we do not know what the impact that changing research experiences may have on a student's chances of reaping the benefits associated with long-term UREs, we assume that this subset of students is likely still interested in STEM careers and could still engage in a subsequent research experience.

Finally, researchers often use the Carnegie classification of research-intensive institutions without disaggregating public and private research-intensive institutions. We found differences between these two types of institutions, which indicates that 
TABLE 6. Recommendations for research mentors with supporting data from Cooper et al. (2019a) and the current study

\begin{tabular}{|c|c|}
\hline Recommendation & Data for support \\
\hline $\begin{array}{l}\text { Provide students with } \\
\text { their perception of } \\
\text { sufficient guidance. }\end{array}$ & $\begin{array}{l}\text { - Students who stayed in their research experience were more likely to select sufficient guidance for their research } \\
\text { projects as a factor (Cooper et al., 2019a). } \\
\text { - For every 1-point increase in a student's GPA, a student was } 1.5 \text { times more likely to stay in research because the } \\
\text { student had sufficient guidance (current study). }\end{array}$ \\
\hline $\begin{array}{l}\text { 2. Explain the why } \\
\text { behind what you are } \\
\text { doing in the lab. }\end{array}$ & $\begin{array}{l}\text { - Students who left their research experiences were more likely to select not gaining important skills or knowledge as } \\
\text { a factor (Cooper et al., 2019a). } \\
\text { - Continuing-generation college students were } 1.9 \text { times more likely than first-generation college students to stay in } \\
\text { research because they were gaining important skills or knowledge (Cooper et al., 2019a). } \\
\text { - Underrepresented minority students were } 2.6 \text { times more likely than white students to consider leaving research } \\
\text { because they were not gaining important skills or knowledge (Cooper et al., 2019a). } \\
\text { - Compared with public R1s, students at private R1s were more likely to report that they were not gaining important } \\
\text { skills or knowledge (current study). } \\
\text { - Compared with first-generation students, non-first generation students were } 1.6 \text { times more likely to stay because } \\
\text { they were gaining skills and knowledge (current study). }\end{array}$ \\
\hline $\begin{array}{l}\text { 3. Be flexible with } \\
\text { students. }\end{array}$ & $\begin{array}{l}\text { - Women were } 4.0 \text { times more likely than men students to consider leaving research because their labs were not } \\
\text { flexible with their time/schedules (Cooper et al., 2019a). } \\
\text { - For every 1-point decrease in a student's GPA, a student was } 2.1 \text { times more likely to consider leaving because the } \\
\text { student did not have enough time to do research (Cooper et al., 2019a). } \\
\text { - Compared with BLNP students, white students were } 1.9 \text { times more likely to leave because they did not have } \\
\text { enough time for research (current study). } \\
\text { - For every 1-point decrease in a student's GPA, a student was } 1.9 \text { times more likely to report leaving because the } \\
\text { student did not have enough time for research (current study). } \\
\text { - Women were } 3.0 \text { times more likely than men to report leaving because their labs were not flexible with their } \\
\text { schedules (current study). } \\
\text { - For every 1-point decrease in a student's GPA, a student was } 2.1 \text { times more likely to report not being flexible with } \\
\text { their schedule (current study). } \\
\text { - Compared with public R1s, students at private R1s, master's-granting, and PUIs were less likely to report that theirs } \\
\text { lab were flexible with their schedules (current study). } \\
\text { - Compared with public R1s, students at master's-granting institutions were less likely to select having enough time as } \\
\text { a factor for staying in research (current study). } \\
\text { Men were } 1.4 \text { times more likely than women to report staying because of having enough time to do research } \\
\text { (current study). }\end{array}$ \\
\hline 4. Pay students. & $\begin{array}{l}\text { - First-generation college students were } 1.9 \text { times more likely than continuing-generation college students to stay in } \\
\text { research because it positively contributes to their financial situations (Cooper et al., 2019a). } \\
\text { - White students were } 2.3 \text { times more likely than Asian students to stay in research because it positively contributes to } \\
\text { their financial situations (Cooper et al., 2019a). } \\
\text { - Compared with public R1s, students at private R1s were less likely to select needing to spend time making money as } \\
\text { a factor for leaving their research experiences (current study). } \\
\text { - Compared with public R1s, students at master's-granting institutions were less likely to select that research } \\
\text { positively contributes to their financial situations as a factor for staying in research (current study). } \\
\text { White students were } 2.0 \text { times more likely than Asian students to report staying because research contributed to } \\
\text { their financial situations (current study). }\end{array}$ \\
\hline $\begin{array}{l}\text { 5. Be nice and create a } \\
\text { positive working } \\
\text { environment. }\end{array}$ & $\begin{array}{l}\text { - Students who stayed in their research experiences were more likely to select a lab mentor who is a PI, faculty } \\
\text { member, graduate student, postdoc or staff member as a factor (Cooper et al., 2019a). } \\
\text { - Students who stayed in their research experiences were more likely to select a positive lab environment; students } \\
\text { who left their experiences were more likely to select a negative lab environment (Cooper et al., 2019a). } \\
\text { - Compared with public R1s, students at master's-granting institutions were less likely to select the overall environ- } \\
\text { ment of the lab as a factor for staying in research (current study). }\end{array}$ \\
\hline
\end{tabular}

these differences may need to be considered in comparisons among institution types in future research.

\section{Limitations}

As with all education research studies, a limitation of any of our conclusions is sampling bias. We attempted to limit sampling bias by recruiting undergraduate researchers from institutions using institutional Listservs. Thus, it required individuals within the institution to send the recruitment message out to their students. We specifically did not want to bias our sample toward undergraduate researchers who had attended a conference or were involved in a specific funded program (e.g., an NSFfunded undergraduate research program) because those students may have extra support; however, we might have been able to recruit a larger number of students if we had recruited using specific research programs.

These data are specific to life sciences undergraduate researchers who conducted research during the academic year in a faculty member's lab. We excluded summer NSF-funded REU programs, so we encourage caution in generalizing our 
results to the experiences of students in these time-intensive summer experiences. Students in REU programs often are paid, have additional programming support, and are not trying to juggle their coursework while doing research, so the challenges may be significantly different for these students. Additionally, we did not include students who were engaged in research in CUREs. The structure and design of CUREs are often quite different from research experiences in faculty member research labs, so additional research would need to be done to explore the factors that lead to positive and negative experiences in CUREs.

Additionally, we only recruited students who conducted undergraduate research in the life sciences, yet we have no reason to believe that these results are discipline specific. Future studies could explore disciplinary differences in student experiences in undergraduate research. We also acknowledge that there is a wide variety of research experiences within life sciences, and future studies could explore subdisciplinary differences that may influence the extent to which students have agency and opportunities to ask their own research questions as opposed to following steps and collecting data (e.g., multiyear ecology experiments compared with short time-frame microbiology experiments).

We attempted to limit sampling bias by not asking for any identifying information about their research mentors or labs. However, we must acknowledge that our conclusions are limited by the students who chose to complete the survey. Students were also asked to reflect on their first UREs, which students may have had difficulties recalling if much time had passed. We were unable to examine student-level demographics across institution type due to the low sample sizes of particular groups, so more targeted recruitment of these groups may be necessary for future studies.

\section{Future Directions}

Future research should consider additional factors that may impact persistence in undergraduate research that were not explicitly addressed in this study. For example, students' motivations for initially engaging in an academic-year URE may influence their decisions to leave. Students who want to explore research as a potential career option may discover that the high level of repetition and failure in research is not enjoyable and may choose to leave to pursue an alternative career. Alternatively, students who aim to get a letter of recommendation for medical school may choose to persist in research until they graduate solely because they need a mentor's letter for their future careers. Teasing apart how these motivators affect student persistence in research through a lens of expectancy value theory could be of interest for future studies.

It could also be important to probe more deeply into a student's experience in undergraduate research and consider the level of responsibility expected of students. It may be relevant to disaggregate whether students have agency over their research projects or whether they are assigned specific tasks to complete to see if agency has an impact on student persistence. Additionally, it could be helpful to consider how programming, funding, or cohort support may influence the experiences of undergraduate researchers who are involved in academic-year research experiences; specifically, a cohort of other undergraduate researchers may help provide community and support to offset some of the negative experiences in a research lab. While these factors are beyond the scope of this study, we encourage future studies to explore their influence on undergraduate researchers.

\section{CONCLUSIONS}

This cross-institutional study demonstrates that, despite institutional differences in the percentage of students who consider leaving UREs, the reasons why students consider leaving are similar across institution types. Student-level demographic differences were observed when data were aggregated across institution type. Thus, conclusions drawn from this study are likely to be more generalizable across institution types.

\section{ACKNOWLEDGMENTS}

We thank the institutions that were willing to send out the survey to students and the students who took the time to share their opinions and experiences. We thank the first cohort of NSF LEAP Scholars along with Joshua Hunter for their help in designing the original survey. We also appreciate the members of Arizona State University's Biology Education Research lab for their feedback on earlier versions of this work. We acknowledge the National Science Foundation S-STEM grant (no. 1644236) that supported our LEAP Scholars. L.E.G. was supported by a National Science Foundation Graduate Fellowship (DGE-1311230).

\section{REFERENCES}

Adedokun, O. A., \& Burgess, W. D. (2011). Uncovering students' preconceptions of undergraduate research experiences. Journal of STEM Education: Innovations and Research, 12(5), 12-22.

Adedokun, O. A., Parker, L. C., Childress, A., Burgess, W., Adams, R., Agnew, C. R., ... \& Lelievre, S. (2014). Effect of time on perceived gains from an undergraduate research program. CBE-Life Sciences Education, 13(1), 139-148.

Agresti, A., \& Franklin, C. A. (2012). Statistics: The art and science of learning from data. New York, NY: Pearson.

Aikens, M. L., Robertson, M. M., Sadselia, S., Watkins, K., Evans, M., Runyon, C. R., ... \& Dolan, E. L. (2017). Race and gender differences in undergraduate research mentoring structures and research outcomes. CBE-Life Sciences Education, 16(2), ar34.

Aikens, M. L., Sadselia, S., Watkins, K., Evans, M., Eby, L. T., \& Dolan, E. L. (2016). A social capital perspective on the mentoring of undergraduate life science researchers: An empirical study of undergraduate-postgraduate-faculty triads. CBE-Life Sciences Education, 15(2), ar16.

Auchincloss, L. C., Laursen, S. L., Branchaw, J. L., Eagan, K., Graham, M. Hanauer, D. I., .. \& Rowland, S. (2014). Assessment of course-based undergraduate research experiences: A meeting report. CBE-Life Sciences Education, 13(1), 29-40

Bauer, K. W., \& Bennett, J. S. (2003). Alumni perceptions used to assess undergraduate research experience. Journal of Higher Education, 74(2), $210-230$.

Bernier, A., Larose, S., \& Soucy, N. (2005). Academic mentoring in college: The interactive role of student's and mentor's interpersonal dispositions. Research in Higher Education, 46(1), 29-51.

Bradley, E. D., Bata, M., Gibbon, H. M. F., Ketcham, C. J., Nicholson, B. A., Pollock, M., \& Dolan, E. (2017). Structure of mentoring in undergraduate research: Multi-mentor models. Scholarship and Practice of Undergraduate Research, 1(2), 35-42.

Bradley, E. H., Curry, L. A., \& Devers, K. J. (2007). Qualitative data analysis for health services research: Developing taxonomy, themes, and theory. Health Services Research, 42(4), 1758-1772.

Brownell, S. E., \& Kloser, M. J. (2015). Toward a conceptual framework for measuring the effectiveness of course-based undergraduate research experiences in undergraduate biology. Studies in Higher Education, 40(3), 525-544

Carnevale, A. P., \& Rose, S. (2013). Socioeconomic status, race/ethnicity, and selective college admissions. 
Carter, F. D., Mandell, M., \& Maton, K. I. (2009). The influence of on-campus, academic year undergraduate research on STEM Ph. D. outcomes: Evidence from the Meyerhoff Scholarship Program. Educational Evaluation and Policy Analysis, 31(4), 441-462.

Cooper, K. M., Auerbach, A. J. J., Bader, J. D., Beadles-Bohling, A. S., Brashears, J. A., Cline, E., ... \& Fuselier, L. (2020a). Fourteen recommendations to create a more inclusive environment for LGBTQ+individuals in academic biology. CBE-Life Sciences Education, 19(3), es6.

Cooper, K. M., \& Brownell, S. E. (2018). Developing course-based research experiences in discipline-based education research: Lessons learned and recommendations. Journal of Microbiology \& Biology Education, 19(2), $1-6$.

Cooper, K. M., Cala, J. M., \& Brownell, S. E. (2021). Cultural capital in undergraduate research: An exploration of how biology students operationalize knowledge to access research experiences at a large, public research-intensive institution. International Journal of STEM Education, $8(6), 1-17$

Cooper, K. M., Gin, L. E., Akeeh, B., Clark, C. E., Hunter, J. S., Roderick, T. B., ... $\&$ Pfeiffer, L. D. (2019a). Factors that predict life sciences student persistence in undergraduate research experiences. PLOS ONE, 14(8), e0220186.

Cooper, K. M., Gin, L. E., Barnes, M. E., \& Brownell, S. E. (2020b). An exploratory study of students with depression in undergraduate research experiences. CBE-Life Sciences Education, 19(2), ar19.

Cooper, K. M., Gin, L. E., \& Brownell, S. E. (2019b). Diagnosing differences in what introductory biology students in a fully online and an in-person biology degree program know and do regarding medical school admission. Advances in Physiology Education, 43(2), 221-232.

Cooper, K. M., Gin, L. E., \& Brownell, S. E. (2020c). Depression as a concealable stigmatized identity: What influences whether students conceal or reveal their depression in undergraduate research experiences? International Journal of STEM Education, 7(1), 1-18.

Cooper, K. M., Hendrix, T., Stephens, M. D., Cala, J. M., Mahrer, K., Krieg, A., ... $\&$ Eledge, B. (2018). To be funny or not to be funny: Gender differences in student perceptions of instructor humor in college science courses. PLOS ONE, 13(8), e0201258.

Daniels, H., Grineski, S. E., Collins, T. W., Morales, D. X., Morera, O., \& Echegoyen, L. (2016). Factors influencing student gains from undergraduate research experiences at a Hispanic-serving institution. CBE-Life Sciences Education, 15(3), ar30.

Deeks, J. (1998). When can odds ratios mislead? Odds ratios should be used only in case-control studies and logistic regression analyses. BMJ: British Medical Journal, 317(7166), 1155.

Dolan, E., \& Johnson, D. (2009). Toward a holistic view of undergraduate research experiences: An exploratory study of impact on graduate/postdoctoral mentors. Journal of Science Education and Technology, 18(6), 487.

Dolan, E. L., \& Johnson, D. (2010). The undergraduate-postgraduate-faculty triad: Unique functions and tensions associated with undergraduate research experiences at research universities. CBE-Life Sciences Education, 9(4), 543-553.

Eagan, M. K., Jr., Hurtado, S., Chang, M. J., Garcia, G. A., Herrera, F. A., \& Garibay, J. C. (2013). Making a difference in science education: The impact of undergraduate research programs. American Educational Research Journal, 50(4), 683-713.

Gilmore, J., Vieyra, M., Timmerman, B., Feldon, D., \& Maher, M. (2015). The relationship between undergraduate research participation and subsequent research performance of early career STEM graduate students Journal of Higher Education, 86(6), 834-863.

Haeger, H., \& Fresquez, C. (2016). Mentoring for inclusion: The impact of mentoring on undergraduate researchers in the sciences. CBE-Life Sciences Education, 15(3), ar36.

Henderson, B. B. (2011). Publishing patterns at state comprehensive universities: The changing nature of faculty work and the quest for status. Journal of the Professoriate, 5(2).

Howitt, S., Wilson, A., Wilson, K., \& Roberts, P. (2010). "Please remember we are not all brilliant": Undergraduates' experiences of an elite, research-intensive degree at a research-intensive university. Higher Education Research \& Development, 29(4), 405-420.
Hu, S., Kuh, G. D., \& Gayles, J. G. (2007). Engaging undergraduate students in research activities: Are research universities doing a better job? Innovative Higher Education, 32(3), 167-177.

Jones, M. T., Barlow, A. E., \& Villarejo, M. (2010). Importance of undergraduate research for minority persistence and achievement in biology. Journal of Higher Education, 81(1), 82-115.

Joshi, M., Aikens, M. L., \& Dolan, E. L. (2019). Direct ties to a faculty mentor related to positive outcomes for undergraduate researchers. BioScience, 69(5), 389-397

Lave, J., \& Wenger, E. (1991). Situated learning: Legitimate peripheral participation. Cambridge, England: Cambridge University Press

Limeri, L. B., Asif, M. Z., Bridges, B. H., Esparza, D., Tuma, T. T., Sanders, D., ... \& Maltese, A. V. (2019). "Where's my mentor?" Characterizing negative mentoring experiences in undergraduate life science research. CBE-Life Sciences Education, 18(4), ar61.

Mabrouk, P. A., \& Peters, K. (2000). Student perspectives on undergraduate research (UR) experiences in chemistry and biology. CUR Quarterly, 21(1), 25-33

Nadile, E. M., Alfonso, E., Barreiros, B. M., Bevan-Thomas, W. D., Brownell, S E., Chin, M. R., ... \& Gomez-Rosado, J. O. (2021). Call on me! Undergraduates' perceptions of voluntarily asking and answering questions in front of large-enrollment science classes. PLOS ONE, 16(1), e0243731.

National Academies of Sciences \& Medicine. (2017). Undergraduate research experiences for STEM students: Successes, challenges, and opportunities. Washington, DC: National Academies Press.

National Academies of Sciences \& Medicine. (2019). The science of effective mentorship in STEMM. Washington, DC: National Academies Press.

President's Council of Advisors on Science and Technology. (2012). Engage to excel: Producing one million additional college graduates with degrees in science, technology, engineering and mathematics. Washington, DC: U.S. Government Office of Science and Technology.

Prunuske, A. J., Wilson, J., Walls, M., \& Clarke, B. (2013). Experiences of mentors training underrepresented undergraduates in the research laboratory. CBE-Life Sciences Education, 12(3), 403-409.

Rowland, S. L., Lawrie, G. A., Behrendorff, J. B., \& Gillam, E. M. (2012). Is the undergraduate research experience (URE) always best? The power of choice in a bifurcated practical stream for a large introductory biochemistry class. Biochemistry and Molecular Biology Education, 40(1), 46-62.

Russell, S. H., Hancock, M. P., \& McCullough, J. (2007). Benefits of undergraduate research experiences. Science, 316(5824), 548-549.

Sandeen, C. (2012). High-impact educational practices: What we can learn from the traditional undergraduate setting. Continuing Higher Education Review, 76, 81-89.

Seymour, E., Hunter, A.-B., Laursen, S. L., \& DeAntoni, T. (2004). Establishing the benefits of research experiences for undergraduates in the sciences: First findings from a three-year study. Science Education, 88(4), 493534.

Thiry, H., \& Laursen, S. L. (2011). The role of student-advisor interactions in apprenticing undergraduate researchers into a scientific community of practice. Journal of Science Education and Technology, 20(6), 771-784.

Thiry, H., Weston, T. J., Laursen, S. L., \& Hunter, A.-B. (2012). The benefits of multi-year research experiences: Differences in novice and experienced students' reported gains from undergraduate research. CBE-Life Sciences Education, 11(3), 260-272.

Titus, M. A. (2006). No college student left behind: The influence of financial aspects of a state's higher education policy on college completion. The Review of Higher Education, 29(3), 293-317.

U.S. News \& World Report. (2021). 2021 Colleges with the lowest acceptance rates: U.S. News rankings. Retrieved March 1, 2021, from www.usnews .com/best-colleges/rankings/lowest-acceptance-rate

Webber, K. L., Laird, T. F. N., \& BrckaLorenz, A. M. (2013). Student and faculty member engagement in undergraduate research. Research in Higher Education, 54(2), 227-249.

Wellek, S. (2017). A critical evaluation of the current "p-value controversy." Biometrical Journal, 59(5), 854-872.

Zydney, A. L., Bennett, J. S., Shahid, A., \& Bauer, K. (2002). Faculty perspectives regarding the undergraduate research experience in science and engineering. Journal of Engineering Education, 91(3), 291-297. 